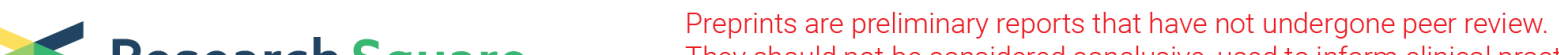 Research Square They should not be considered conclusive, used to inform clinical practice, or referenced by the media as validated information.
}

\section{First DNA Barcoding Based Record of Lysiosquillina Maculata (Fabricius, 1793) (Crustacea: Stomatopoda) From Chennai Coast, Tamil Nadu, India}

\section{Babu C}

Fishery Survey of India, Royapuram, Chennai

Silambarasan K ( $\nabla$ silambuplankton@hotmail.com )

FISHERY SURVEY OF INDIA BEACH ROAD VISAKHAPATNAM ANDHRA PRADESH INDIA https://orcid.org/0000-0001-5805-1562

\section{Anrose A}

Fishery Survey of India, Royapuram, Chennai

Tiburtius A

Fishery Survey of India, Royapuram, Chennai

\section{Research Article}

Keywords: biodiversity, Mantis shrimp, mtCOI, Phylogeny, Genetic distance

Posted Date: January 3rd, 2022

DOI: https://doi.org/10.21203/rs.3.rs-1197983/v1

License: (c) (i) This work is licensed under a Creative Commons Attribution 4.0 International License. Read Full License 


\section{Abstract}

Taxonomic identification of mantis shrimp Lysiosquillina maculata through DNA barcoding analysis collected from Kasimedu fisheries harbour, Chennai coast, Tamil Nadu, India. The mitochondrial cytochrome oxidase sub unit I gene ( $\mathrm{mtcol}$ ) with $650 \mathrm{bp}$ region was sequenced for phylogenetic analysis. The present record, mitochondrial gene sequences were used to identify the mantis shrimp Lysiosquillina maculata. This is the first confirmed record of Indian waters and the $\mathrm{mt}$ COI sequence was deposited in GenBank. The neighbor joining method was used for phylogenetic analysis. The pair wise genetic distance calculated with 08 closely related species varied form $0.03-0.404 \%$. Phylogenetic tree based on 13 protein coding genes shows that Lysiosquillina maculata has a closer phylogenetic relationship to Harpiosquilla harpax.

\section{Introduction}

A total of 500 species belonging to more than 120 genera, 18 families and 7 superfamilies were recorded in worldwide (Ahyong 1997; Ahyong and Harling 2000; Ahyong 2012). According to Ahyong (2001), under the family Lysiosquillidae Giesbrecht, 1910 there are three genera and four valid species, Lysiosquillina glabriuscula (Lamarck 1818), L. lisa (Ahyong and Randall 2001), L. maculata (Fabricius 1793), and L. sulcata (Manning 1978b). Although, some misidentification and unauthenticated information has been reviewed on this group, but the through the taxonomic investigation and generation of molecular data are precisely attempted throughout the world (Tang et al. 2010). Moreover, the morphological characters are not enough to the identification of species level. Recently, Hebert et al. (2003) suggested that DNA barcodoing technique is made to use of the cytochrome c oxidase subunit-I (COI) in the mitochondrial DNA (mtDNA) markers of an organism, it is rapid and effective species identification by studying the genetic variability among different taxa, and recently the technique has been used to identify the varied life-history stages of single species (Vogler and Monaghan 2007). DNA barcoding is very well developed in worldwide it has been successfully applied in a wide range of animals, including both terrestrial and aquatic taxa (Hebert et al. 2004a; Ward et al. 2005; Hajibabaei et al. 2006; Wakabayashi et al. 2006; Hubert et al.2008). This method has become popular in identifying and studying the genetic diversity of stomatopods by comparing the sequence of other stomatopods of the unknown species with the earlier collected sequences of stomatopod (Barber and Erdmann 2000; Barber et al. 2002; Barber et al. 2006; Barber and Boyce 2006; Tang 2010). So far, a very few study was conducted in the diversity of stomatopods in east coast of India through DNA barcode methods (Kundu et al. 2018).

The common banded/striped/zebra mantis shrimp Lysiosquillina maculata was first described as Squilla maculata by Fabricius (1793) from India orientali, which was reported as Lysiosquilla maculata by Kemp (1913) from Kakinada, Chennai, Andaman and Nicobar Islands in Indian waters. Lyla et al. (1997) reported L. maculata from Parangipettai, while Kathirvel (2008) and Dev Roy and Gokul (2012) list the species occurring in Indian waters. However, Trivedi et al. (2020). Synonymised L. maculata with Lysiosquilla tredecimdentata Holthuis, 1941. The recent collection of Lysiosquillina specimens from 
Chennai were critically analysed and confirmed that they belonged to Lysiosquillina maculata (Fabricius 1793) through DNA barcoding, the results of which are presented here.

\section{Materials And Methods}

\section{Sampling and morphological identification}

The mantis shrimp Lysiosquillina maculata were collected from trawl by-catches at Kasimedu, Fisheries Harbour, Chennai. The specimen was collected by hand picking and its identification was carried out using standard guidelines (Manning 1978; Ahyong et al. 2008). The specimen was preserved in $70 \%$ alcohol and deposited in the museum of Fishery Survey of India, Chennai.

\section{Genomic DNA isolation, PCR and sequencing}

The sample was used for the extraction of total genomic DNA using Phenol Chloroform method, standardized by CAGL. Quality of the genomic DNA was assessed using $0.7 \%$ agarose gel along with $1 \mathrm{~kb}$ DNA ladder as size standard and the quantity of the genomic DNA was assessed in Biophotometer (Eppendorf). Amplification of $\mathrm{COI}$ gene was carried out for all the test samples using $\mathrm{COI}$ Forward and Reverse primers. PCR-generated amplicon for 06 samples were confirmed and purified using GeneJET PCR purification kit (Thermo Scientific, EU-Lithuania) to remove the primer dimer and other carryover contaminations. The quality of the products was assessed using $2 \%$ agarose gel along with $100 \mathrm{bp}$ DNA marker as size standard and the products were found to be good for sequencing.

Purified PCR products were prepared for Cycle sequencing using the Big Dye ${ }^{\circledR}$ Terminator 3.1 sequence kit (Applied Biosystems, Foster City, California, USA). After cycle sequencing, the products were purified using Ethanol-EDTA purification protocol to remove the un-incorporated dNTP's, ddNTP's and primer dimer. After purification the products were dissolved in $12 \mu \mathrm{l} \mathrm{Hi-Di} \mathrm{formammide} \mathrm{and} \mathrm{the} \mathrm{samples} \mathrm{were}$ subjected for denaturation at $95^{\circ} \mathrm{C}$ for 5 mins. Denatured products were used for sequencing in forward and reverse directions using Genetic Analyzer 3500 (Life Technologies Corporation, Applied Biosystems ${ }^{\circledR}$, California 94404, USA) as per manufacture's instruction. Sequences were aligned, edited, and analyzed using Clustal W and Mega software version 6 (Tamura et al. 2013).

\section{Dataset preparation and sequence analysis}

The sequence was converted to FASTA format and submitted to nucleotide BLAST through the NCBI website (http://www.ncbi.nlm.nih.gov/). The first five sequence matches with highest similarity to database references (mat ident) were analysed for species consistency. All matches were analysed using the percent similarity score.

Taxonomic designations were derived from phylogenetic analysis of mtDNA gene sequences. Sequence was analysed using Bioedit software (Version 7.2.5) (Hall 2004). Final alignment the sequence was compared with the sequences deposited in the National Center for Biotechnology Information (NCBI) in GenBank database using the Basic Local Alignment Search Tool (BLAST). Neighbor-joining (NJ) trees of 
Kimura two-parameter (K2P) distance were created to provide a graphic representation of the pattern of divergence between species (Saitou and Nei 1987). The 1000 bootstrap replications were performed in MEGA 6.0 software (Kumar et al. 2016). The K2P genetic distances for defining the species, genus and family levels were based on Ward et al. (2005).

\section{Results And Discussion}

The genus Lysiosquillina contains 04 species that are difficult to identify the morphological characters. More over these characters are not enough to the accurate identification of the species level. In the present study, the mtDNA sequences of $\mathrm{COI}$ gene of the mantis shrimp Lysiosquillina maculata belongs to the family Lysiosquillina were initially compared with same genus of 03 different species like, $L$. glabriuscula (Lamarck 1818), L. lisa Ahyong and Randall (2001) and L. sulcata (Manning 1978b). It was the first conformational record in Indian waters. The GenBank accession number is MT490885. A 650bp segment of the 5 ' margin of mitochondrial cytochrome oxidase subunit I gene is currently used for classification of molecular taxonomy. The A,T,G and C contents of the sequence L. maculata were $154 \%$, $140 \%, 86 \%$ and $51 \%$ respectively. The GC content was observed at $31.8 \%$ in the species. Other sequence variation was not observed among those specimens.

In the present study we have examined the morphological characters and identified the specimen as Lysiosquillina maculata (Fabricius 1793). We recorded two specimens with total length ranged from 161 to $178 \mathrm{~mm}$ and the specimens are having the characters of ocular scales triangular, erect, and inclined anteriorly. The carapace is convex and broad the rostrum is cordiform-shaped occasionally sub triangular, width usually greater than length. The blunt longitudinal carina present on anterior third plate. Dactylus of raptorial claw possessing 8-11 teeth; normally 10-11 but the larger females it may be varied in 10-11 teeth. Mandibular palp present and 3 segmented. TS8 sternal keel rounded. Uropodal protopod is triangular lobe and ventero laterally anterior to articulation of each uropod and uropodal exopod proximal segment outer margin with 7-9 movable spines; endopod with distal 3/4 dark. Dorsum base colour pale yellow, with black transverse bands.

The genetic information of taxonomically identified species is essential for perform the genetic similarity search in the global database (Moritz and Cicero 2004). Hence, before submitting any novel sequences in GenBank and BOLD, it is essential to identify the studied specimens. Earlier, the genetic information on the two known species of genus Harpiosquilla, H.harapax and $H$. raphidea are accessible in the GenBank database. The generated sequence of $L$. maculata from Indian waters were first time annotated (650 bp) and submitted in to the GenBank datasets. The generated sequences are shown $91 \%$ similarity with Lysiosquillina maculata in both GenBank and BOLD database.

The genetic distance of L. maculata with eight closely related species were calculated based on Kimura's 2-parameter method (Table 1). The pair wise genetic distance was calculated it varied from (0.03-0.404) that showed the smaller genetic distance indicate a close genetic relationship whereas a large genetic distance indicate a more distant genetic relationship. Genetic variation within populations can be lost 
through genetic drift or bottleneck in the population (You et al. 2001). Hebert et al. (2003) suggested that DNA bar coding has the powerful tool to provide valuable insight in to patterns of genetic divergence affected by species level or ecological variation. The average genetic distance among species does not exceed the average genetic distance between "sister" species.

The phylogenetic relationship of Lysiosquillina maculata with 01 closely related species and one out group were analysed in this study. Complete mitochondrial genes of these 04 species are available on GenBank. The maximum-liklihood evolutionary tree (ML tree) was constructed by MEGA 7 (Kumar et al. 2016) based on 1 st and 2 nd codon sequences of 19 protein coding genes.

In the ML phylogenetic tree, Lysiosquillina maculata and Harpiosquilla harpax formed one clade with strong support. But Oratosquilla oratoria, Traisquilla profunda, Heterosquillatri carinata, Austrosquilla tsangi, Platysquilla eusebia, Madeirasquilla tuerkayi and Lysiosquilla maculata in the second clade. These two clades mentioned above were all classified into family Lysiosquillidae or order Lysiosquilloidea (Fig. 1). All the above results shows that L. maculata has close phylogenetic relationship to $H$. harapax. As expected, species from the same genera were clustered in to a two different clades with well supported bootstrap proportion (Steinke et al. 2005).

\section{Declarations}

\section{Acknowledgements}

We thank the Director General of Fishery Survey of India, Mumbai, Ministry of Fisheries, Govt. of India for providing necessary permissions and facilities. Our sincere thanks to Dr. M. Kathirvel, Former Principal Scientist of Central Institute of Brackish water Aquaculture (ICAR), Chennai, for critical review of the manuscript and provided valuables suggestions for its improvement.

\section{Conflicts of interest/Competing interests}

The authors declare that they have no known competing financial interests or personal relationships that could have appeared to influence the work reported in this manuscript.

\section{Ethics approval (including appropriate approval or waivers)}

Not applicable

\section{Consent to participate (include appropriate statements)}

Not applicable

\section{Consent for publication (include appropriate statements)}

Not applicable 
Availability of data and material (data transparency)

All the relevant data have been presented in the manuscript

Code availability (software application or custom code)

Not applicable

\section{Author's contributions}

All the authors of this manuscript have contributed significantly towards the execution of this work.

\section{References}

1. Ahyong ST (1997) Phylogenetic analysis of the Stomatopoda (Malacostraca). J Crust Biol 17:695715

2. Ahyong ST (2001) Revision of the Australian stomatopod Crustacea. Rec Aus Mus, Suppl 26:1-326

3. Ahyong ST (2012) The Marine Fauna of New Zealand: Mantis Shrimps (Crustacea: Stomatopoda). NIWA Biodiv Memo 125:1-112

4. Ahyong ST, Randall JE (2001) Lysiosquillina lisa, a new species of mantis shrimp from the Indo-West Pacific (Stomatopoda: Lysiosquillidae). J South Asia Nat Hist 5(2):135-140

5. Ahyong ST, Chan TY, Liao YC (2008) A catalogue of the mantis shrimps (Stomatopoda) of Taiwan. National Ocean Taiwan University. Keelung 191 pp

6. Ahyong ST, Harling C (2000) The phylogeny of the stomatopod Crustacea. Aus J Zool 48(6):607642

7. Barber PH, Boyce SL (2006) Estimating diversity of Indo-Pacific coral reef stomatopods through DNA barcoding of stomatopod larvae. Proc R Soc London Ser B Biol Sci 273:2053-2061

8. Barber PH, Erdmann MV (2000) Molecular systematics of the Gonodactylidae (Stomatopoda) using mitochondrial cytochrome oxidase C (Subunit 1) DNA sequence data. J Crust Biol 20(2):20-36

9. Barber PH, Erdmann MV, Palumbi SR (2006) Comparative phylogeography of three codistributed stomatopods: origin and timing of regional lineage diversification in the coral triangle. Evolu 60(9):1825-1839

10. Barber PH, Moosa MK, Palumbi SR (2002) Rapid recovery of genetic diversity of stomatopod populations on Krakatau: temporal and spatial scales of marine larval dispersal. Proc R Soc London Ser B Biol Sci 269(1500):1591-1597

11. Dev Roy MK, Gokul A (2012) A Checklist of Indian Stomatopods (crustacea: stomatopoda). J Environ \& Sociobiol 9(1):87-92

12. Fabricius JC (1793) Entomologia Systematica Emendata et Aucta. Secundum Classes, Ordines, Genera, Species. Adjectis Synonimis, Locis, Observationibus, Descriptionibus, 2. pp. vii+519. Hafniae 
13. Hajibabaei M, Janzen DH, Burns JM, Hallwachs W, Hebert PDN (2006) DNA barcodes distinguish species of tropical Lepidoptera. Proc Nat Acad Sci Unit Stat of America 103:968-971

14. Hall BG (2004) Comparison of the accuracies of several phylogenetic methods using protein and DNA sequences. Mol Biol \& Evol 22(3):792-802

15. Hebert PDN, Cywinska A, Ball SL, DeWaard JR (2003) Biological identifications through DNA barcodes. Proc R Soc London Ser B Biol Sci 270:313-321

16. Hebert PDN, Penton EH, Burns JM, Janzen DH, Hallwachs W (2004a) Ten species in one: DNA barcoding reveals cryptic species in the neotropical skipper butterfly Astraptesful gerator. Proc Nat Acad Sci Unit Stat of America 101:14812-14817

17. Holthuis LB (1941) The Stomatopoda of the Snellius Expedition. Biological Results of the Snellius Expedition XII. Temmin 6:241-294

18. Hubert N, Hanner R, Holm E et al (2008) Identifying Canadian freshwater fishes through DNA barcodes. PLoS ONE 3(6):e2490. DOI: 10.1371/journal.pone.0002490

19. Kathirvel M (2008) Biodiversity of Indian Stomatopods. Glimpses of Aquatic Biodiversity - Rajiv Gandhi Chair Spl. Pub 7:93-102

20. Kemp S (1913) An account of the Crustacea Stomatopoda of the Indo-Pacific region, based on the collection in the Indian Museum. Mem Ind Mus 4: 1-217, Figs. 1-10, pls. 1-10

21. Kumar S, Steche G, Tamura K (2016) Mega7: Molecular Evolutionary Genetics Analysis version 7.0 for bigger datasets. Mol Biol Evol 33(7):1870-1874

22. Kundu S, Rath S, Tyagi K, Chakraborty R, Pakrashi A, Kumar V, Chandra K (2018) DNA barcoding of Cloridopsis immaculata: genetic distance and phylogeny of stomatopods. Mitochondrial DNA Part B 3(2):955-958

23. Lamarck JBPA (1818) Histoire naturelle des animaux sans vertèbres prsentant les caractéres généraux et particuliers de ces animaux, leur distribution, leur classes, leurs families, leurs genres, et la citation des principales espèces qui s'y rapportent; précédée d'une introduction offrant la détermination des caracteres essentiels, de l'animal, sa distinction du vegetal et des autres corps naturelles, enfin, l'exposition des principes fondamentaux de la zoologie 5. Deterville, Paris, pp 1-612

24. Lyla PS, Chandrasekaran VS, Khan SA (1997) Stomatopoda of Parangipettai coast. Centre of Advanced Study in Marine Biology. Annamalai University, Parangipettai, p 47

25. Manning RB (1978) New and rare stomatopod crustacea from the Indo-West Pacific region. Smith Contr Zool 264:1-44

26. Moritz C, Cicero C (2004) DNA barcoding: promise and pitfalls. PLoS Biol 2:e354

27. Saitou N, Nei M (1987) Neighbor-joining method: A new method for reconstructing phylogenetic trees. Mol Biol Evol 4:406-425

28. Steinke D, Vences M, Salzbruger W, Meyer A (2005) Tax I: A Software tool for DNA barcoding using distance methods. Philos Trans Royal Soci-B: Biol Sci 360:1975-1980 
29. Tamura K, Stecher G, Peterson D, Filipski A, Kumar S (2013) MEGA 6: Molecular Evolutionary Genetics Analysis version 6.0. Mol Biol Evol 30:2725-2729

30. Tang RWK, Yau C, Chuenng W (2010) Identification of stomatopod larvae (Crustacea: Stomatopoda) from Hong Kong waters using DNA barcodes. Mol Ecol Res 10:439-448

31. Trivdedi JN, Ahyong ST, Vachhrajani KD, Biju Kumar A (2020) An annotated checklist of mantis shrimps of India (Crustacea: Stomatopoda). Zootaxa 4768(2):221-238

32. Vogler AP, Monaghan MT (2007) Recent advances in DNA taxonomy. J Zool Syst Evol Res 45:1-10

33. Wakabayashi T, Suzuki N, Sakai M, Ichii T, Chow S (2006) Identification of ommastrephid squid paralarvae collected in northern Hawaiian waters and phylogenetic implications for the family Ommastrephidae using mtDNA analysis. Fish Sci 72:494-502

34. Ward RD, Zemlak TS, Innes BH, Last PR, Hebert PDN (2005) DNA barcoding Australia's fish species. Philos Trans Royal Soc Lond Series B, Biol Sci 360:1847-1857

35. You F, Wang K, Xiang J, Xu C (2001) Comparative analysis of biochemical genetic structure and variance between natural and cultured stocks on the left-eyed flounder, Paralichthys olivaceus off Shandong coastal waters. Oceanologia et Limnol Sini 32:512-512

\section{Tables}

Table 1 is not available with this version.

\section{Figures}




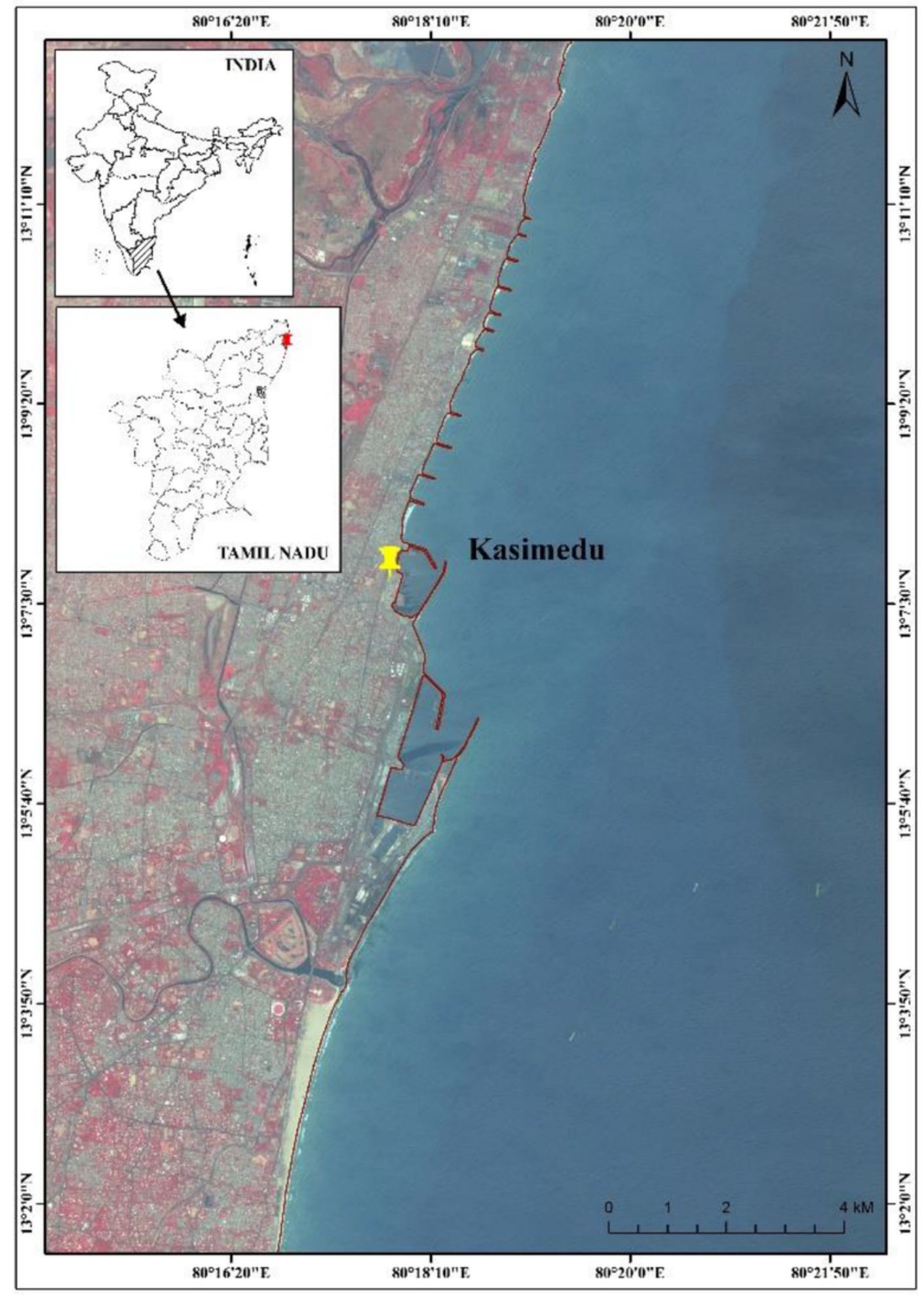

Figure 1

Collection site of the Lysiosquillina maculata from Kasimedu fisheries harbour 


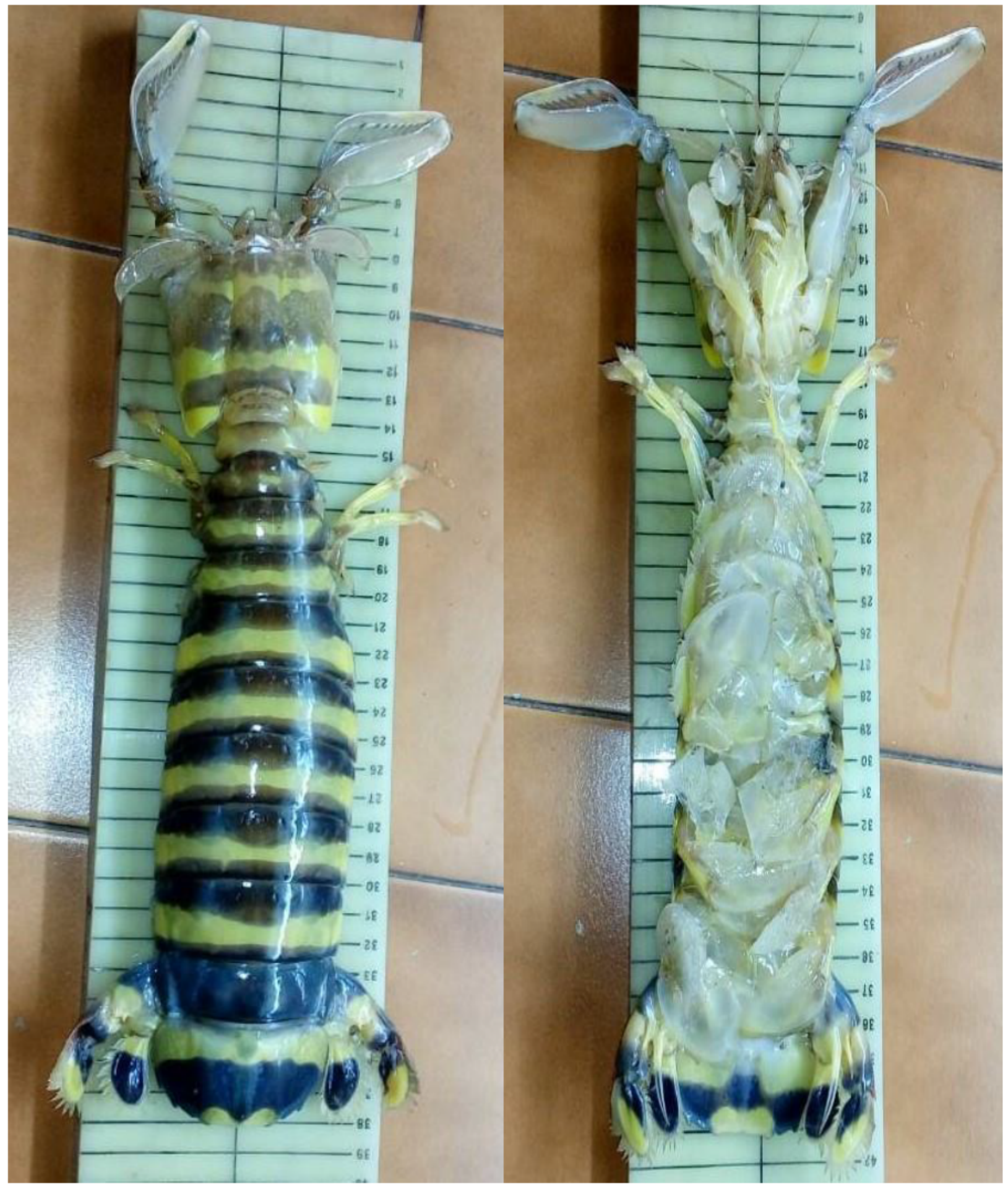

(a)

(b)

Figure 2

Lysiosquillina maculata (TL-178 mm) (a) dorsal view (b) ventral view 


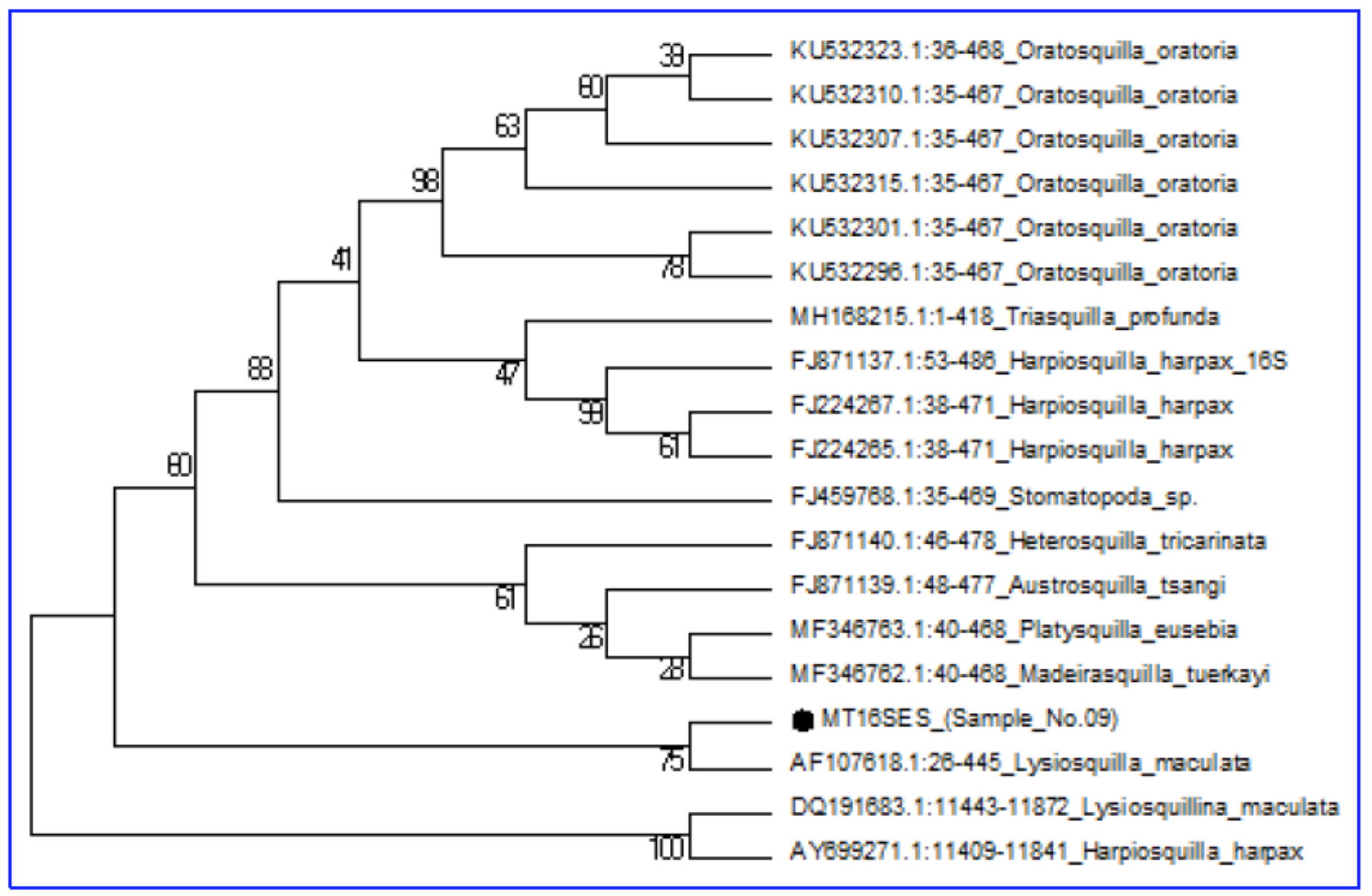

\section{Figure 3}

Phylogenetic analysis of L. maculata with closely related species by Neighbour Joining method. The black dots represent the generated sequences in this study. 